(RESEARCH ARTICLE)

\title{
Prospects and challenges of cash crop production in Nigeria: The case of cashew (Anacardium occidentale, Linn.)
}

Qudus Adebayo Ogunwolu 1,*, Chinweike Abednego Ugwu 2, Modinat Adewunmi Alli ${ }^{3}$, Kehinde Ademola Adesanya ${ }^{4}$, Mutiat Oluwaseyi Agboola-Adedoja ${ }^{5}$, Adejoke Adebusola Adelusi ${ }^{6}$ and Ayodele Oladipo Akinpelu ${ }^{7}$

Economics and Extension department, Cocoa Research Institute of Nigeria, P.M.B. 5244, Ibadan, Oyo State, Nigeria, 1234567.

Publication history: Received on 20 December 2020; revised on 28 December 2020; accepted on 30 December 2020

Article DOI: https://doi.org/10.30574/wjarr.2020.8.3.0503

\begin{abstract}
The paper examined the prospects and challenges of cashew production in Nigeria. Qualitative and quantitative data which were used to identify these challenges and prospects were retrieved from research findings, literatures, journals and reports. Strengths, Weaknesses, Opportunities and Threats (SWOT) analysis was used to highlight the strengths and weaknesses inherent in the internal environment of the cashew sector as well as the opportunities and threats from the external environment of the cashew sector. The paper takes a step further by employing Threats Opportunities Weaknesses and Strengths (TOWS) analysis matrix to come up with models that can be employed to improve the cashew sector in Nigeria. Some of the prospects identified include the potential employment creation, increasing cultivation area and evidenced value addition. While some of the challenges identified include poor pricing of cashew nuts, lack of proper policy intervention and underutilization of cashew apple. Government is advised to set up a cashew marketing board and provide proper policy intervention to improve prices, production levels and provide employment opportunities.
\end{abstract}

Keywords: SWOT analysis; TOWS analysis; Cashew sector; Marketing board

\section{Introduction}

Cashew (Anacardium occidentale L.), a tree crop which originated from Brazil and was initially being planted to help alleviate erosion has become one of the most recognized cash crops in the world today. Cashew now serves as a source of raw materials, food and income for individuals and nations [1]. Cashew was introduced to Nigeria as far back as the 16th century by the Portuguese traders at a time when the crop had no economic value. Proper cultivation of the crop however, started in the 1950's [2]. The crop has since grown both locally and internationally in economic value and relevance. It is of special importance to the third world countries such as Vietnam, Guinea, India, Nigeria, Tanzania, Brazil and Ivory Coast, because it has been a major source of foreign exchange to these countries. The importance of cashew (most especially the nut) in Nigeria cannot be over-emphasized; the crop contributes substantially to the nation's national income, gross domestic product (GDP) and most importantly foreign exchange [3]. The crop generated about 24billion naira export revenue for the country in 2017 [4]. Cashew is cultivated widely across the country due to the favorable climate and soil in Nigeria [5]. Despite the promising potentials of cashew in Nigeria, farmers are said to be experiencing many constraints in cashew production, processing and marketing [3]. These constraints as well as changing climate have resulted in a drop in the level of cashew production in Nigeria in recent years [6]. The study is aimed at identifying the prospects and challenges in cashew production by studying the internal and external

\footnotetext{
${ }^{*}$ Corresponding author Qudus Adebayo Ogunwolu

Economics and Extension department, Cocoa Research Institute of Nigeria, P.M.B. 5244, Ibadan, Oyo State, Nigeria 1234567. 
environment in cashew production in Nigeria and coming up with models which can be employed to explore the prospects and limit the challenges involved in the production process.

SWOT analysis is a tool used to critically examine the internal and external environment of an Organisation. This method of analysis is done by strategically identifying the strengths and weaknesses which are the internal factors and the existing opportunities and threats which serve as the external factors affecting the operations of an organization [7]. Similarly, TOWS analysis and matrix is a technique which helps to fix the internal weaknesses of an organization and eliminate the external threats by leveraging on the strength and opportunities and by interacting the internal factors with external factors [8]. Furthermore, SWOT and TOWS analysis are popular for their use in business organisations, the technique can also be employed for evaluating and providing solutions for sectorial performances as used by [8]

\section{Material}

This paper employs the findings of various past researches to identify the internal and external factors affecting cashew production in Nigeria. Strengths, Weaknesses, Opportunities and Threats (SWOT) analysis was used to identify the factors involved while Threats, Opportunities, Weaknesses and Strengths (TOWS) matrix was used to form the models which improves cashew production in Nigeria.

\section{Swot analysis}

S denotes Strengths, W: Weaknesses, O: Opportunities and T: Threats.

\subsection{Strengths (S)}

\subsubsection{Huge contribution to the country's non-oil export earnings (S1)}

It is reported that agriculture contributes a whopping 88\% to the Nigeria's non-oil export earnings [9]. Cashew's contribution to this quota of non-oil export earnings in the country is estimated to be between 7 to 8 percent [5]. [2] reported that the export value of cashew nuts in Nigeria between 2010 to 2014 ranges between $\$ 25 \mathrm{million}$ to $\$ 35$ million, this is a huge annual contribution from a single crop considering it is not a crop which is given serious focus by the government.

\subsubsection{Development of fast bearing varieties (S2)}

Cashew tree takes about 5 to 6 years on the average to mature and produce quality nuts. However, Cocoa Research Institute of Nigeria (CRIN), with the research mandate for cashew and some other cash crops have been able to come up with a better quality nut production which takes less than required years to mature [10]. The institute introduced a better variety of cashew called the 'Brazilian Jumbo', which reaches maturity in less than five years, it is bigger in size and the cashew nut shell liquid (CNSL) oil obtained from it is of greater quality [11].

\subsubsection{Existing value addition to cashew production (S3)}

There have been a couple of studies examining the value addition of cashew production in Nigeria. [12] emphasized the importance and economic advantage that come with value addition. The products that can be obtained from cashew include Juice, Quash, Syrup, Jam, Wine, Candy and Vinegar, all of which are derivable from the cashew apple. Cocoa Research Institute of Nigeria (CRIN) has been able to develop some of these products. Farmers are getting sensitized on the value addition that can be derived from the neglected parts of cashew tree by extension agents [13]. 


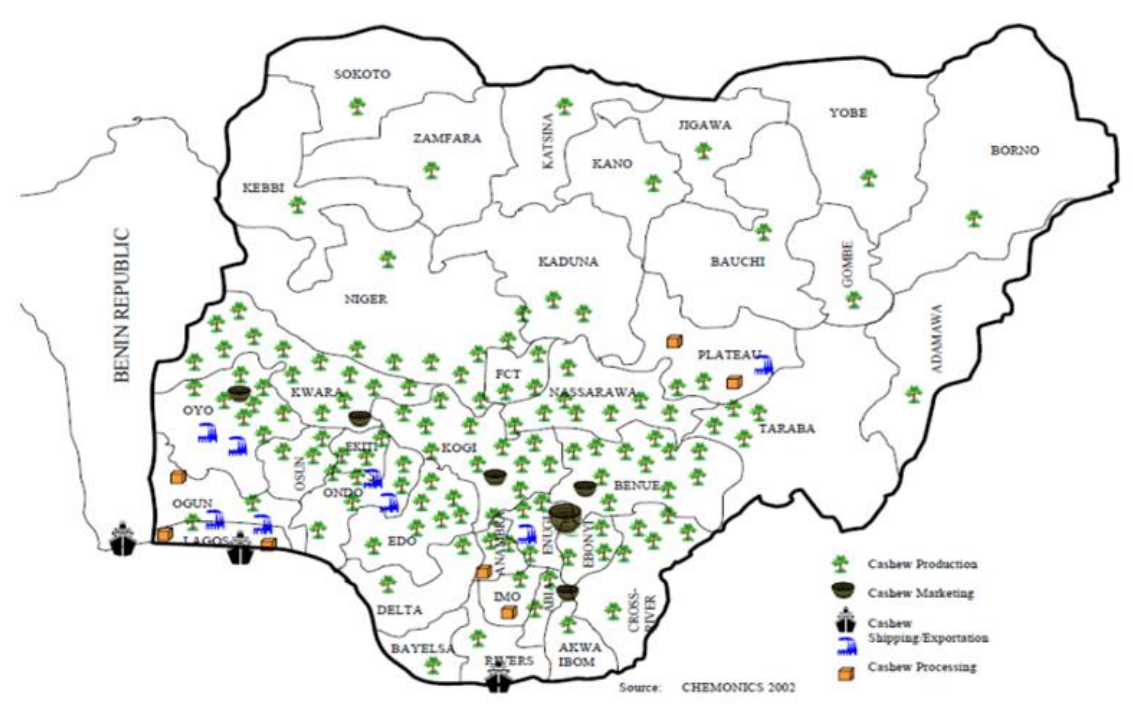

Figure 1 Map of Nigeria showing cashew producing states

Source: Chemonics, 2002

\subsubsection{Ease of Cultivation (S4)}

Cashew is generally an easy crop to cultivate; it can grow in virtually any region in the country, and will even blossom where the soil is well drained [14]. The ease involved in the cultivation of the crop is also due to its ability to germinate and perform well with minimum attention [4].

\subsection{Weakness (W)}

\subsubsection{Inadequate Labour (W1)}

According to [3], farmers have lamented the inadequacy of labour at every stage of cashew production, most especially during planting, weeding and harvesting. The impact of labour on planting precision, weed control, harvesting and processing cannot be over-emphasized [3]. According to [14], the scarcity of willing manpower for cashew cultivation has resulted to high cost of labour; this can be attributed to the rising need for a white collar job among Nigerian youths at the expense of core agriculture.

\subsubsection{Underutilization of cashew apple (W2)}

Cashew is mainly planted for its nut due to the economic value attached to it; this has led to the neglect of the cashew apple as most of the apples accompanying the nut are often treated as a waste product despite the several prospective uses of the apple [15]. According to [16], the wastage of cashew apple by farmers depletes their potential income from cashew farming.

\subsubsection{Cashew Nut Processing (W3)}

One of the major weaknesses of cashew production in Nigeria is lack of adequate processing. [2] and [4] amongst other researches on cashew production in Nigeria stated that only about 5 percent of the total cashew nuts produced are further processed. This can be attributed to the lack of required machinery and presence of a few production companies in need of the inputs. This causes a loss of prospective income for the country because processed cashew nuts are expected to have higher costs considering the value added to the crop.

\subsubsection{Poor Quality Cashew Nut Due to Lack of Proper Storage (W4)}

One of the problems faced by farmers while trying to market cashew nuts in Nigeria is loss of quality of the cashew nut due to improper or lack of storage facilities. [2] opined that poor quality of exportable cashew is indeed one of the biggest challenges faced by cashew farmers in Nigeria. 


\subsection{Opportunities (0)}

\subsubsection{Provision of employment opportunities (01)}

[17]opined that the role of agriculture in employment creation in Nigeria cannot be underestimated and cashew nut production which involves labour intensive activities is considered to be a major source of employment opportunity in the agriculture sector. Cashew nut production and processing sector is a potential source of substantial foreign exchange and employment generation [18]. Every stage of the cashew cultivation and cashew processing serves as a source of income for both the smallholder farmers and women [2].

\subsubsection{One of the top producing nations in the world (O2)}

Nigeria is one of the top ten producers of cashew nut in the world at the moment [18]. Although there has been a drop in the production and yield of cashew nut in the country in the past five years, the country still manages to produce about 100,000 tons of cashew nut yearly [19].

\subsubsection{Increasing Area of Cultivation (03)}

There is a strong potential for increase in cashew production in Nigeria due to the increasing areas dedicated to its cultivation. There was a time that cashew was predominant only in south west, south east and a few states in north central; however, cultivation has extended to states where people have not paid attention to in the past. There was a certain boom in cashew production from 1990 to 2010 according to [19], this boom was attributed to an increasing cultivation area rather than increase in crop yield [2].

\subsubsection{One of the top exporting countries (O4)}

Nigeria is one of the top raw cashew nut (RCN) exporting countries in the globe with about 3.43 percent share of the total export in world market [19]. It is estimated that about 70 percent of the total cashew produced in Nigeria is commercialized out of which 90 percent is being exported globally [18].

\subsection{Threats (T)}

\subsubsection{Diseases and Pests (T1)}

According to [10], there are over ten different pests affecting the cultivation of cashew in Nigeria some of them are as follows; cashew stem girdler (Analeptes trifasciata Fabricius), fruit scraper (Pachnoda cordata Drury), trunk and root borer (Plocaederus ferrugineus L.), red-banded thrips (Selenothrips rubrocinctus Giard). These pests are a threat to cashew production in Nigeria as many farms and plantations have battled with these pests over the years and it has impacted their output negatively. Furthermore, there are numerous diseases associated with cashew production in Nigeria however; the most threatening is the Lasiodiplodia theobromae which was reported as the cause of the loss of about 40 percent of cashew crops annually [20].

\subsubsection{Poor Access to Market Information (T2)}

[3], in their study on the constraints of cashew production, reported that access to market information is indeed to threat to cashew farming in Nigeria as majority of the respondents were of the opinion that poor access to information is a problem for cashew farmers whilst in different degrees. [21] opined that knowledge and market information has a way of boosting agricultural production and development.

\subsubsection{Poor Pricing (T3)}

Nigeria's cashew nuts are reported to be selling at a discount in the international market [2], reported that the Nigerian cashew sells at 20 to 30 percent discount in the world market which is a disadvantage and threat to cashew production in Nigeria because price is always a motivator for farmers. They reported that Nigerian cashew is poorly priced due to low quality cashew nut, small kernel size and poor peelability.

\subsubsection{Poor Infrastructure (T4)}

Lack of adequate infrastructure is a common problem to all the sectors in Nigeria and cashew production and processing sector is no different. Cashew production and processing requires standard processing technologies, constant electricity, good access roads for farmers to move the crop to the market, access to water and so on [14]. The few cashew processing firms in Nigeria provide these services by themselves and this adds to their cost of production which affects the competitiveness of the product in international market. 


\subsubsection{Lack of Proper Policy Intervention (T5)}

[3] identified inadequate credit facilities as one of the major problems faced by cashew farmers in Nigeria, this position was backed by [5] who concluded that cashew production does not get enough protection as far as policy intervention is concerned.

\subsubsection{Pilfering (T6)}

One of the major threats faced by cashew farmers is pilfering. [4], identified pilfering as a major cause of concern for cashew farmers. [22], also observed the theft and pilfering going on in cashew farms across the country.

\subsection{TOWS analysis matrix}

TOWS analysis was created to provide a solution for the problems that might be facing a sector by interacting the internal factors with the external factors [8].

\begin{tabular}{|l|l|l|}
\hline & Strengths & Weakness \\
\hline Opportunities & $\begin{array}{l}\text { S4xO3= SOA } \\
\text { S1x04= SOC }\end{array}$ & $\begin{array}{l}\text { W1x01= } \\
\text { WOA }\end{array}$ \\
& & \\
\hline Threats & T2 & W2 \\
& S1xT3= STA & T5 \\
& S3xT5= STB & T3 \\
& & T4 \\
& & T6 \\
\hline
\end{tabular}

The TOWS matrix was used to develop models. The interactions led to the discussion below.

\subsection{1. $S 4 \times O 3=S O A$ Model}

[3] Emphasized on the ease of cultivation of cashew in Nigeria. In this model, farmers can capitalize on the fact that cashew is easy to cultivate and requires less supervision compared to some other crops to further increase their cultivation area. The ease of cultivation of cashew should further encourage new farmers to go into cashew production thereby increasing the cultivation area.

\subsection{2. $\mathrm{S} 1 \mathrm{xO}=\mathrm{S}=\mathrm{SOC}$ Model}

We have been able to ascertain through previous literatures that cashew exports contribute greatly to the nation's nonoil export earnings. It is impossible to achieve such a feat without attaining a level of exports. There is an increase in demand for cashew nuts in Europe due to the use of its raw materials by confectioneries and industrial trade [2]. Nigeria is one of the top ten cashew nut exporting countries in the world, the country can leverage on the rising demand and increase production which will inevitably increase export volume and will result in a rise in non-oil export earnings.

\subsection{3. $W 1 \times 01=W O A$ Model}

Youth unemployment is one major issue facing the Nigerian economy; as at 2017 youth unemployment rate stood at 13.41 percent and has been on the rise ever since [23]. The cashew production sector serves as a source of employment for many individuals, inspite of this factor farmers still complain of inadequate labour. Perhaps there is a potential for the sector to employ even more individuals and this would inevitably reduce the level of unemployment in the country.

\subsubsection{S1xT3=STA Model}

[14] Noted that the low price paid to cashew farmers is a major concern for the farmers and has also been attributed to the fall in yield. Cashew exports still contributes substantially to the nation's non-oil exports despite the poor pricing challenge faced by the crop in the global market due to less quality. [2] Related the poor pricing of cashew output to poor peelability and processing which reduces the quality of the nuts. There is a potential to increase the level of the country's non-oil exports by simply providing the necessary processing machines that would enable the farmers to 
produce quality cashew and attain better prices in the global market. Perhaps the re-establishment of a proper functioning marketing board by the government will boost the price of Nigerian cashew nuts.

\subsubsection{S3xT5= STB Model}

There is a respectable level of the value addition in terms of products and by products of cashew which has been documented over the years. Products like jam, juice, wine and chocolate can be gotten from the apple while gum can be derived from the trunk. [14], opined that a proper government intervention will help promote production and reduce waste. Perhaps strong government intervention in terms of provision of credit facilities, infrastructure and training of farmers will help galvanize the activities of processors and farmers where value addition is concerned.

\subsubsection{W2 Model}

The amount of cashew apple that goes to waste is too much in Nigeria. There are so many products that can be gotten from the cashew apple. [15] Proposed collaboration between cashew processing companies and government agencies such as the National Centre for Agricultural Mechanization (NCAM) to improve processing technologies and educate the cashew nut processors against the wastage of cashew apple. This may serve as a way of improving the economic value of the cashew tree and probably improve the standard of living of smallholder farmers.

\subsubsection{T6 Model}

The increasing economic value of cashew nuts though a benefit for farmers, it has also shifted the attentions of pilfers to the crop. In the past few years cashew farms have been the target of pilfers and the rising insurgency of bandits attacking farmlands have been helpful also. Perhaps the rising case of pilfering is one of the reasons for the fall in cashew nut production over the past ten years as portrayed by [19]. Pilfering has been identified as a major problem where cashew cultivation and marketing is concerned. The government should ensure that cashew farmlands, cashew nut and farmers are secured in other to encourage the farmers to produce more nuts.

\section{Conclusion}

This paper has been able to identify the internal and external factors affecting cashew in Nigeria using SWOT analysis and providing a solution to some of the issues using TOWS matrix. There is no doubt that cashew production, processing and marketing in Nigeria has some challenges, in other to alleviate these challenges the government need to focus on the areas of strength in this sector and also identify the potential opportunities available in the sector. Farmers are advised to increase cultivation area so as to improve the scale of production since the crop can grow in the arid north and rain forest south regions of the country. The government should endeavor to set up a special cashew marketing board that will oversee the standardization and pricing of cashew products in Nigeria. This will no doubt improve the economic value of the crop and propel increase in yield and production volume. Also, government needs to invest and provide the proper policy intervention such as training by extension agents and availability of credit facilities for cashew farmers. This will not only drive up production but will also provide employment for the youths and ultimately increase cashew exports.

\section{Compliance with ethical standards}

\section{Acknowledgments}

I cannot express enough gratitude to my mentor, Dr. A O Akinpelu, whose guidance and continuous encouragement has ensured the success of this work. My gratitude is also extended to my coauthors for their unique contributions and constructive criticisms.

\section{Disclosure of conflict of interest}

The authors declare that they have no conflict of interest.

\section{References}

[1] Salau SA, Popoola GO, Nofiu BN. Analysis of cashew nuts marketing in Kwara State, Nigeria. Fuoye Journal of Agriculture and Human Ecology. 28 Mar 2018; 1(1). 
[2] Adeigbe 00, Olasupo FO, Adewale BD, Muyiwa AA. A review on cashew research and production in Nigeria in the last four decades. Scientific Research and Essays. 15 Mar 2015; 10(5): 196-209.

[3] Oluyole KA, Yahaya AT, Uwagboe EO, Mokwunye IU, Agbeniyi So, Orisajo SB, Otunoye AH, Ndagi I, Shittu TR, Aderolu IA. Constraints in Cashew Production Among Cashew Farmers in Southwestern Nigeria. Journal of Basic and Applied Research International. Feb 2015; 17: 116-20.

[4] Lawal JO, Uwagboe EO. Cost Effectiveness of Intercropping Patterns by Cashew Farmers in Oyo State, Nigeria. Int. J. For. Anim. Fish. Res. (IJFAF) AI Publications. 2017; (1): 27-30.

[5] Oluyole KA, Agbeniyi SO, Ayegbonyin KO. Competitiveness of Cashew Production in Nigeria. International Journal of Research in Agriculture and Forestry. 2017; 4(8): 1-7.

[6] Bello OD, Akponikpè PB, Ahoton EL, Saidou A, Ezin AV, Kpadonou GE, Balogoun I, Aho N. Trend Analysis Of Climate Change And Its Impacts On Cashew Nut Production (Anacardiumoccidentalel.) In Benin. Octa Journal of Environmental Research. 1 Sep 2016; 4(3).

[7] Ghazinoory S, Abdi M, Azadegan-Mehr M. SWOT methodology: a state-of-the-art review for the past, a framework for the future. Journal of business economics and management. 11 Apr 2011; 12(1): 24-48.

[8] ABOUD A, ŞAHINLI MA. SWOT and TOWS analysis: an application to cocoa in Ghana. Scientific Papers: Management, Economic Engineering in Agriculture \& Rural Development. 1 Jan 2019; 19(1).

[9] Esan VI, Lawi MB, Okedigba I. Analysis of cashew farmers adaptation to climate change in South-Western Nigeria. Asian Journal of Agricultural Extension, Economics \& Sociology. Mar 2018; 27: 1-2.

[10] Asogwa EU, Hammed LA, Ndubuaku TC. Integrated production and protection practices of cashew (Anacardium Occidentale) in Nigeria. African Journal of Biotechnology. 2008; 7(25).

[11] Hammed LA, Anikwe JC, Adededji AR. Cashew nuts and production development in Nigeria. Am. Eurasian J. Sci. Res. 2008; 3(1): 54-61.

[12] Lawal JO, Jayeola CO. Economic analysis of cocoa wine produced from cocoa powder. JOURNAL OF FOOD AGRICULTURE AND ENVIRONMENT. 1 Apr 2007; 5(2).

[13] Uwagboe EO, Adeogun SO, Odebode SO. Constraints of farmers in cashew production: a case study of Orire LGA of Oyo State, Nigeria. Journal of Agricultural and Biological Science. 2010; 5(4): 27-31.

[14] Agbongiarhuoyi AE, Uwagboe EO, Ibiremo OS, Olasupo FO, Aigbekaen EO. Assessment of Factors Associated with Low Yield of Cashew among Farmers in Growing Areas of Nigeria. Journal of Experimental Agriculture International. 2015; 258-66.

[15] Nwosu C, Adejumo OA, Udoha WN. Cashew apple utilization in Nigeria: Challenges and prospects. Journal of Stored Products and Postharvest Research. 29 Feb 2016; 7(2): 29-31.

[16] Lawal J0, Oduwole 00, Shittu TR, Muyiwa AA. Profitability of value addition to cashew farming households in Nigeria. African crop science journal. 2011; 19(1).

[17] Ogunleye EK. Synthesis of the Literature on Employment Creation in Nigeria's Agriculture and Agro-Industries in the Context of Inclusive Growth. Include Platform. May 2017.

[18] Alawode 00, Adeniranye AV. Competitiveness of Nigerian Cashew Nuts in the Global Market (1961-2016): An Application of Vector Error Correction Model (VECM). 2020.

[19] FAOSTAT. Countries by commodity. FAO, Rome, Italy. 2018.

[20] Adejumo T0. Crop protection strategies for major diseases of cocoa, coffee and cashew in Nigeria. African Journal of Biotechnology. 11 Aug 2005; 4(2): 143-50.

[21] Oladele OI. Multilinguality of farm broadcast and agricultural information access in Nigeria. Nordic Journal of African Studies. 31 Dec 2006; 15(2).

[22] Yerima TF, Oluduro O. Criminal Law Protection of Property: A Comparative Critique of the Offences of Stealing and Theft in Nigeria. J. Pol. \& L. 2012; 5: 167.

[23] M Ajide F. Asymmetric Influence Of Financial Development On Unemployment In Nigeria. Ilorin Journal of Economic Policy. 2020; 7(2): 39-52. 